\title{
Philosophy and the Arts
}

Royal Institute of Philosophy Supplement: 71

Edited by Anthony O’Hear 


\section{Royal Institute of Philosophy Supplements}

The Royal Institute of Philosophy Supplements are published twice a year. Institutional subscribers to the journal Philosophy receive the supplements as part of their subscription. The following supplements are available to purchase as books.

$\begin{array}{rlll}\text { Volume } 38 & 1995 & \text { Philosophy and Technology } \\ 39 & 1995 & \text { Karl Popper: Philosophy and } \\ 40 & 1996 & \text { Philosophy and Pluralism } \\ 41 & 1996 & \text { Verstehen and Human Understanding } \\ 42 & 1997 & \text { Thought and Language } \\ 43 & 1998 & \text { Current Issues in Philosophy } \\ & & \text { of Mind } \\ 44 & 1999 & \text { German Philosophy since Kant } \\ 45 & 1999 & \text { Philosophy and Public Affairs } \\ 46 & 2000 & \text { Logic, Cause \& Action } \\ 47 & 2000 & \text { Philosophy, the Good, the True } \\ 48 & 2001 & \text { Philosophy at the New Millennium } \\ 49 & 2001 & \text { Naturalism, Evolution and Mind } \\ 50 & 2002 & \text { Time, Reality \& Experience } \\ 51 & 2002 & \text { Logic, Thought and Language } \\ 52 & 2003 & \text { Philosophy and the Emotions } \\ 53 & 2003 & \text { Minds and Persons } \\ 54 & 2004 & \text { Modern Moral Philosophy } \\ 55 & 2004 & \text { Agency and Action } \\ 56 & 2005 & \text { Philosophy, Biology and Life } \\ 57 & 2005 & \text { The Philosophy of Need } \\ 58 & 2006 & \text { Political Philosophy } \\ 59 & 2006 & \text { Preferences and Well-Being } \\ 60 & 2007 & \text { Narrative and Understanding Persons } \\ 61 & 2007 & \text { Philosophy of Science } \\ 62 & 2008 & \text { Being: Developments in } \\ 63 & 2008 & \text { Contemporary Metaphysics } \\ 64 & 2009 & \text { Kant and Philosophy } \\ 65 & 2009 & \text { Conceptions of Philosophy } \\ 66 & 2010 & \text { Philosophy as Therapeia } \\ 67 & 2010 & \text { The Metaphysics of Consciousness } \\ 68 & 2011 & \text { Philosophy and Religion } \\ 70 & 2011 & \text { Philosophy and the Environment } \\ & 2012 & \text { Human Nature } \\ & & \end{array}$

(ISBN 0521558166)

(ISBN 0521558158)

(ISBN 0521567505)

(ISBN 0521587425)

(ISBN 0521587417)

(ISBN 0521639271)

(ISBN 0521667828)

(ISBN 0521667844)

(ISBN 0521785103)

(ISBN 0521785111)

(ISBN 0521005086)

(ISBN 0521003733)

(ISBN 0521529670)

(ISBN 0521529662)

(ISBN 0521537347)

(ISBN 0521537339)

(ISBN 0521603269)

(ISBN 0521603560)

(ISBN 0521678455)

(ISBN 0521678447)

(ISBN 0521695597)

(ISBN 0521695589)

(ISBN 9780521714099)

(ISBN 9780521718967)

(ISBN 9780521735445)

(ISBN 9780521748513)

(ISBN 9780521138581)

(ISBN 9780521138574)

(ISBN 9780521165150)

(ISBN 9780521173919)

(ISBN 9781107615984)

(ISBN 9781107696075)

(ISBN 9781107651975)

From Volume 13 onwards the Series is published by Cambridge University

Press and some earlier titles are also available.

This journal issue has been printed on FSC-certified paper and cover board. FSC is an independent, non-governmental, not-for-profit organization established to promote the responsible management of the world's forests. Please see www.fsc.org for information. 


\section{Philosophy and the Arts}

ROYAL INSTITUTE OF PHILOSOPHY SUPPLEMENT: 71

EDITED BY

Anthony O'Hear

\section{CAMBRIDGE \\ UNIVERSITY PRESS}


PUBLISHED BY THE PRESS SYNDICATE OF THE UNIVERSITY OF CAMBRIDGE

The Pitt Building, Trumpington Street, Cambridge, CB2 1RP, United Kingdom

CAMBRIDGE UNIVERSITY PRESS

The Edinburgh Building, Cambridge CB2 8RU, United Kingdom

32 Avenue of the Americas, New York, NY 10013-2473, USA

477 Williamstown Road, Port Melbourne, VIC 3207, Australia

C/Orense, 4, planta 13, 28020 Madrid, Spain

Lower Ground Floor, Nautica Building, The Water Club, Beach Road, Granger Bay, 8005 Cape Town, South Africa

(C) The Royal Institute of Philosophy and the contributors 2013

Printed in the United Kingdom at MPG Books Ltd.

Typeset by Techset Composition Ltd, Salisbury, UK

A catalogue record for this book is available from the British Library

ISBN 978-1-107-66174-5

ISSN 1358-2461 


\section{Contents}

List of Contributors $\quad$ V

Preface vii

On Sculpture

ANTHONY O'HEAR

For the Love of Art: Artistic Values and Appreciative Virtue MATTHEW KIERAN

Authorial Intention and the Pure Musical Parameters PETER KIVY

Popular Song as Moral Microcosm: Life Lessons from Jazz

Standards

JERROLD LEVINSON

Is there still life in Still Life?

ANTHONY SAVILE

On Cinematic Genius: Ontology and Appreciation

PAISLEY LIVINGSTON

The Poetic Image

MARTIN WARNER

Depiction

JOHN HYMAN

The Problem of Perfect Fakes

M.W. ROWE

Music, Metaphor and Society: Some Thoughts on Scruton ROBERT GRANT

Brilliant Performances

AARON RIDLEY

Artistic Truth

ANDY HAMILTON

Index of Names 


\section{List of Contributors}

Anthony O'Hear - Royal Institute of Philosophy

Matthew Kieran - Leeds University

Peter Kivy - Rutgers University, New Brunswick

Jerrold Levinson - University of Maryland

Anthony Savile - Kings College London

Paisley Livingston - Lingnan University

Martin Warner - University of Warwick

John Hyman - Queens College, Oxford

Mark Rowe - University of East Anglia

Robert Grant - University of Glasgow

Aaron Ridley - University of Southampton

Andy Hamilton - University of Durham 